\title{
Direct effect of ice sheets on terrestrial bicarbonate, sulphate and base cation fluxes during the last glacial cycle: minimal impact on atmospheric $\mathrm{CO}_{2}$ concentrations
}

\author{
M. Tranter ${ }^{\mathrm{a}, *}$, P. Huybrechts ${ }^{\mathrm{b}}$, G. Munhoven ${ }^{\mathrm{a}, \mathrm{c}}$, M.J. Sharp ${ }^{\mathrm{d}}$, G.H. Brown ${ }^{\mathrm{e}}$, \\ I.W. Jones ${ }^{\text {a }}$, A.J. Hodson ${ }^{\mathrm{f}}$, R. Hodgkins ${ }^{\mathrm{g}}$, J.L. Wadham ${ }^{\mathrm{a}}$ \\ ${ }^{\mathrm{a} B r i s t o l}$ Glaciology Centre, School of Geographical Sciences, University of Bristol, Bristol BS 8 1SS, UK \\ ${ }^{\mathrm{b}}$ Geografisch Instituut, Vrije Universiteit Brussel, Pleinlaan 2, B-1050 Brussels, Belgium \\ ${ }^{\mathrm{c}}$ Laboratoire de Physique Atmosphérique et Planétaire, Institut d'Astrophysique et de Géophysique, Université de Liège, B-4000 Liège, Belgium \\ ${ }^{\mathrm{d}}$ Department of Earth and Atmospheric Sciences, University of Alberta, Edmonton, Canada T6G $2 E 3$ \\ ${ }^{\mathrm{e}}$ Centre for Glaciology, Institute of Geography and Earth Sciences, University of Wales, Aberystwyth SY23 3DB, UK \\ ${ }^{\mathrm{f}}$ Department of Geography, University of Sheffield, Sheffield S10 2TN, UK \\ ${ }^{\mathrm{g}}$ Department of Geography, Royal Holloway, University of London, Egham TW20 OEX, UK
}

\begin{abstract}
Chemical erosion in glacial environments is normally a consequence of chemical weathering reactions dominated by sulphide oxidation linked to carbonate dissolution and the carbonation of carbonates and silicates. Solute fluxes from small valley glaciers are usually a linear function of discharge. Representative glacial solute concentrations can be derived from the linear association of solute flux with discharge. These representative glacial concentrations of the major ions are $\sim 25 \%$ of those in global river water. A 3-D thermomechanically coupled model of the growth and decay of the Northern Hemisphere ice sheets was used to simulate glacial runoff at 100-year time steps during the last glacial cycle (130 ka to the present). The glacially derived fluxes of major cations, anions and Si over the glaciation were estimated from the product of the glacial runoff and the representative glacial concentration. A second estimate was obtained from the product of the glacial runoff and a realistic upper limit for glacial solute concentrations derived from theoretical considerations. The fluxes over the last glacial cycle are usually less than a few percent of current riverine solute fluxes to the oceans. The glacial fluxes were used to provide input to an oceanic carbon cycling model that also calculates changes in atmospheric $\mathrm{CO}_{2}$. The potential change in atmospheric $\mathrm{CO}_{2}$ concentrations over the last glacial cycle that arise from perturbations in glacial solute fluxes are insignificant, being $<1 \mathrm{ppm}$. (C) 2002 Elsevier Science B.V. All rights reserved.
\end{abstract}

Keywords: Glaciers; Chemical denudation rates; Global geochemical cycles; Atmospheric $\mathrm{CO}_{2}$ concentrations

\section{Introduction}

Terrestrial chemical weathering of silicate minerals is a fundamental, long-term control on the concentration of $\mathrm{CO}_{2}$ in the atmosphere (Walker et al., 1981; Berner et al., 1983). On shorter time scales, the balance between terrestrial chemical weathering of

\footnotetext{
* Corresponding author. Tel.: +44-117-928-8307; fax: +44-117928-7878.

E-mail address: m.tranter@bristol.ac.uk (M. Tranter).
} 
carbonates and marine carbonate precipitation is also important (Holland, 1978). During the last glaciation, most terrestrial chemical weathering is believed to have occurred in non-glaciated terrain, since it is thought that continental ice sheets reduce chemical weathering rates by one or two orders of magnitude. This is principally because soil $\mathrm{CO}_{2}$ sources are absent, significant rock-water contact is limited to the ice sheet margins and runoff rates are low (Kump and Alley, 1994). However, Gibbs and Kump (1994) suggested that there could be a significant reduction in atmospheric $\mathrm{CO}_{2}$ concentrations at the last glacial maximum (hereafter LGM, $\sim 18$ ka B.P.) if sufficiently high rates of chemical weathering occurred around the margins of the large ice sheets. Modelling suggested that runoff from non-glaciated terrain at the LGM was little different from present-day values and that global rates of chemical weathering were similar to the present-day if ice sheets and glacial runoff performed little chemical weathering. By contrast, rates could be as much as $\sim 180 \%$ those of the present-day if significant chemical weathering occurred in ice marginal and glacial environments. Hence, it is possible that glacial chemical weathering has a major effect on global chemical weathering fluxes and atmospheric $\mathrm{CO}_{2}$ concentrations. Another modelling study crudely estimated glacial runoff at the LGM from annual precipitation falling on ice, minus a correction for evaporation (Ludwig et al., 1999). The concentration of $\mathrm{CO}_{2}$ sequestered from the atmosphere was as calculated by Sharp et al. (1995). This study concluded that there was little change in atmospheric $\mathrm{CO}_{2}$ attributable to glacial chemical denudation.

Recently, data have been accumulating on solute denudation rates and the geochemical weathering processes that occur in a range of glacial environments (Sharp et al., 1995, 1999; Hodgkins et al., 1998; Wadham et al., 1999; Tranter et al., 2002). Our intention here is to utilise these data to derive solute fluxes in dilute, turbid glacial runoff over the last glacial cycle of ice sheet growth and decay ( $130 \mathrm{ka}$ B.P. to the present). The potential impact of these glacial solute fluxes on atmospheric $\mathrm{CO}_{2}$ concentrations over the last glacial cycle is calculated by using a state-of-the-art marine carbon cycling model (Munhoven and François, 1996). The following sections detail our current understanding of chemical weathering in glaciated environments, which is a necessary backdrop to the flux calculations.

\subsection{Chemical weathering in glaciated environments}

Chemical denudation rates in catchments containing small valley glaciers are some 1.2-2.6 times higher than the continental average (Sharp et al., 1995 and references therein), and are comparable with rates of chemical erosion in temperate catchments with equivalent specific runoff (Anderson et al., 1997). This is attributed to the high water flux (Anderson et al., 1997), high rock/water ratios, and reactive, freshly comminuted, silt and clay-sized surfaces with adhering microparticles (Tranter et al., 1993). A high flux of dilute, turbid runoff is a characteristic of present glaciated catchments, whether or not the runoff originates from warm-, polythermalor cold-based glaciers (Hallet et al., 1996; Hodson et al., 1997), since runoff accesses glacial debris in subaerial, ice-marginal, subglacial or proglacial environments. It is likely that runoff from the great ice sheets during the last glaciation (Arnold and Sharp, 1992; Tranter, 1996) was also turbid, since glaciogenic debris produced during either the last or previous glaciations could be accessed in subglacial, icemarginal and/or proglacial environments. Hence, it is not unreasonable to assume that glacial chemical weathering rates around the margins of the ablating ice sheets were comparable to current temperate zone weathering rates during the last glaciation.

It has been argued that chemical weathering was less important beneath the mid-latitude Pleistocene ice sheets because subglacial drainage may have been less widespread than beneath valley glaciers (Kump and Alley, 1994). While this is almost certainly the case, it is likely that a distributed drainage system existed beneath the warm-based interior and that channels existed near the ice sheet margin (Arnold and Sharp, 1992; Alley, 1996). Recent modelling and theoretical studies also require extensive subglacial drainage systems beneath certain sectors of ice sheets (Clark et al., 1996). For example, the so-called binge/purge model of the Laurentide Ice Sheet assumes a waterfilled tunnel system under much of the area prone to surge (MacAyeal, 1993), and water-saturated till or a water-filled tunnel system is believed to exist under the Antarctic ice streams (Bentley, 1987), although 
water fluxes away from the ice margin are likely to be low. Subglacial water can also be produced by geothermal heating and energy from internal deformation. Crevasses that occur in the vicinity of ice streams and near ice sheet margins are means by which meltwater generated by surface ablation is transferred to the subglacial drainage system. Hence, there is potential for meltwater to be transferred into a subglacial drainage system and to remain near the bed for several kilometres before emerging at the ice margin. In modern valley glaciers, most of the meltwater-transported solute is acquired during the first few hours of water-rock contact (Sharp, 1996). Hence, chemical weathering in ice sheet marginal environments is likely to have generated solute fluxes similar to those measured in meltwaters emerging from beneath contemporary valley glaciers if significant quantities of water flowed at the ice sheet bed.

\subsection{Mechanisms of glacial chemical weathering}

Carbonation reactions are one possible source of solute in glacial runoff, particularly during periods of high runoff (Tranter et al., 1993) which coincide with periods of maximum solute flux (Sharp et al., 1995). Carbonation draws $\mathrm{CO}_{2}$ out of the atmosphere, since it is a combination of the relatively slow diffusion of gaseous $\mathrm{CO}_{2}$ into solution (Eq. (1))

$$
\mathrm{CO}_{2}(\mathrm{~g}) \rightleftarrows \mathrm{CO}_{2}(\mathrm{aq})
$$

and the acid hydrolysis of minerals such as calcite and anorthite (as an end-member example of feldspar weathering), as shown by Eqs. (2) and (3), respectively.

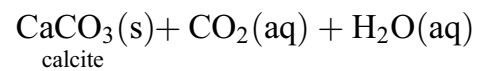

$$
\begin{aligned}
& \rightleftharpoons \mathrm{Ca}^{2+}(\mathrm{aq})+2 \mathrm{HCO}_{3}^{-}(\mathrm{aq}) \\
& \mathrm{CaAl}_{2} \mathrm{Si}_{3} \mathrm{O}_{8}(\mathrm{~s})+2 \mathrm{CO}_{2}(\mathrm{aq})+2 \mathrm{H}_{2} \mathrm{O}(\mathrm{aq}) \\
& \text { anorthite (Ca-feldspar) } \\
& \rightleftharpoons \mathrm{Ca}^{2+}(\mathrm{aq})+2 \mathrm{HCO}_{3}^{-}(\mathrm{aq}) \\
& +\mathrm{Al}_{2} \mathrm{Si}_{2} \mathrm{O}_{6}(\mathrm{OH})_{2}(\mathrm{~s}) \\
& \text { partially weathered feldspar surfaces }
\end{aligned}
$$

Carbonation is thought to occur in partially filled channelised drainage systems where there is free access to atmospheric gases (Brown et al., 1994). Another suite of reactions dominate in the water-full distributed drainage system beneath warm-based valley glaciers (Tranter et al., 2002). These are carbonate hydrolysis,

$$
\begin{gathered}
2 \mathrm{CaCO}_{3}(\mathrm{~s})+\mathrm{H}_{2} \mathrm{O}(\mathrm{aq}) \\
\rightleftharpoons 2 \mathrm{Ca}^{2+}(\mathrm{aq})+\mathrm{HCO}_{3}^{-}(\mathrm{aq})+\mathrm{CO}_{3}^{2-}+\mathrm{OH}^{-}(\mathrm{aq})
\end{gathered}
$$

and coupled sulphide oxidation and carbonate dissolution.

$$
\begin{aligned}
\underset{\text { pyrite }}{4 \mathrm{FeS}_{2}(\mathrm{~s})+} & 16 \mathrm{CaCO}_{3}(\mathrm{~s})+15 \mathrm{O}_{2}(\mathrm{aq})+14 \mathrm{H}_{2} \mathrm{O}(\mathrm{aq}) \\
\rightleftharpoons & 16 \mathrm{Ca}^{2+}(\mathrm{aq})+16 \mathrm{HCO}_{3}^{-}(\mathrm{aq}) \\
& +8 \mathrm{SO}_{4}^{2-}(\mathrm{aq})+\underset{\text { ferric oxyhydroxides }}{4 \mathrm{Fe}(\mathrm{OH})_{3}(\mathrm{~s})}
\end{aligned}
$$

The initial oxygen content of the supraglacial ice melt is therefore one of the limiting factors that determines the amount of chemical weathering that occurs in subglacial environments, unless other subglacial oxidants exist. In addition, subglacial chemical weathering may be promoted by protons produced by the microbial oxidation of organic matter (Tranter et al., 2002).

$$
\begin{gathered}
\mathrm{C}_{\text {organic }}(\mathrm{s})+\mathrm{H}_{2} \mathrm{O}(\mathrm{aq})+\mathrm{O}_{2}(\mathrm{aq}) \\
\rightleftharpoons \mathrm{CO}_{2}(\mathrm{aq})+\mathrm{H}_{2} \mathrm{O}(\mathrm{aq}) \\
\rightleftharpoons \mathrm{H}^{+}(\mathrm{aq})+\mathrm{HCO}_{3}^{-}(\mathrm{aq})
\end{gathered}
$$

\subsection{Glacial chemical weathering and atmospheric $\mathrm{CO}_{2}$}

Recent analysis of subglacial waters sampled at Haut Glacier d'Arolla, Switzerland (Tranter et al., 2002) and of waters upwelling from subglacial environments at Finsterwalderbreen, Svalbard (Wadham et al., 2000) shows that carbonate hydrolysis and carbonate dissolution driven by sulphide oxidation (Eqs. (4) and (5)) provide much of the dissolved inorganic carbon in the runoff. Hence, subglacial chemical weathering is unlike chemical weathering in other terrestrial environments in that atmospheric $\mathrm{CO}_{2}$ is 
not required to dissolve carbonate minerals, either directly or indirectly, via root or microbial respiration in soils. This observation has fundamental implications for the way in which glacial runoff may perturb atmospheric $\mathrm{CO}_{2}$ concentrations, since if this type of weathering was dominant beneath the great ice sheets, the balancing of the carbonate cycle by marine precipitation of biogenic carbonate gives rise to a net return of $\mathrm{CO}_{2}$ to seawater, from where it may degas into the atmosphere.

$$
\begin{gathered}
\mathrm{Ca}^{2+}(\mathrm{aq})+2 \mathrm{HCO}_{3}^{-}(\mathrm{aq}) \\
\rightleftharpoons \mathrm{CaCO}_{3}(\mathrm{~s})+\mathrm{CO}_{2}(\mathrm{aq})+\mathrm{H}_{2} \mathrm{O}(\mathrm{l})
\end{gathered}
$$

Hence, subglacial chemical weathering may stimulate the oceans to release $\mathrm{CO}_{2}$ and increase atmospheric $\mathrm{CO}_{2}$ concentrations, particularly during deglaciation when glacial runoff fluxes are high. The fate of glacially derived $\mathrm{SO}_{4}^{2-}$ in the oceans confounds the magnitude of this effect, since some may be lost by the precipitation of gypsum (Holland, 1978)

$$
\begin{gathered}
\mathrm{Ca}^{2+}(\mathrm{aq})+\mathrm{SO}_{4}^{2-}(\mathrm{aq})+2 \mathrm{H}_{2} \mathrm{O}(\mathrm{l}) \\
\rightleftharpoons \underset{\text { gypsum }}{\rightleftharpoons} \mathrm{CaSO}_{4} \cdot 2 \mathrm{H}_{2} \mathrm{O}(\mathrm{s})
\end{gathered}
$$

or by sulphate reduction in marine sediments (Holland, 1978), which potentially adds $\mathrm{HCO}_{3}{ }^{-}$to the oceans.

$$
\begin{gathered}
\mathrm{SO}_{4}^{2-}(\mathrm{aq})+2 \mathrm{C}_{\mathrm{org}}(\mathrm{s})+2 \mathrm{H}_{2} \mathrm{O}(\mathrm{l}) \\
\rightleftharpoons \mathrm{H}_{2} \mathrm{~S}(\mathrm{aq})+2 \mathrm{HCO}_{3}^{-}(\mathrm{aq})
\end{gathered}
$$

Interactions between $\mathrm{H}_{2} \mathrm{~S}$ and $\mathrm{Fe}$ (II) in marine sediments, as well as diffusive exchange and reoxidation of the $\mathrm{H}_{2} \mathrm{~S}$ in the overlying oxic waters, render the calculation of the overall impact of the reduction of glacially derived marine sulphate problematical. A full examination of the marine S-cycle over glacialinterglacial time scales is beyond the scope of this paper.

The following methodology, although imperfect, allows the first exploration since that of Gibbs and Kump (1994) of the potential impact of glacial chemical weathering on atmospheric $\mathrm{CO}_{2}$ concentrations during the last glacial cycle. We anticipate better estimation of glacial fluxes as more pertinent data and better modelling techniques become available.

\section{Methodology}

\subsection{Estimation of runoff}

A 3-D thermomechanically coupled model of the growth and decay of the Northern Hemisphere ice sheets (Huybrechts and T'siobbel, 1995) was used to estimate glacial runoff over the last $130 \mathrm{ka}$ (Fig. 1). The model has been tested against and found to be consistent with the Greenland and Antarctic ice sheets (Huybrechts, 1990; Huybrechts et al., 1991). The main inputs to the ice sheet model are bed topography, mean annual surface temperature and the mass balance. The inputs to the mass-balance model are data sets for present-day mean monthly sea-level air temperature and mean monthly precipitation rates obtained from standard climatologies, which are perturbed in different environments to take into account the effects of ice sheet elevation, atmospheric temperature change and the moisture-holding capacity of the overlying column of air. The mass balance model distinguishes between snow accumulation and runoff and is driven by a temperature record over the last 130 ka derived from the GRIP ice core (Dansgaard et al., 1993). Following procedures successfully adopted for the Greenland ice sheet (Reeh, 1989), the melting rate is set proportional to the yearly sum of positive degree days at the ice sheet surface, and the final amount of runoff is obtained as the sum of meltwater that does not refreeze in the snowpack and of any water resulting from basal melting. The ice sheet model has been shown to be able to reproduce the growth and decay of the Northern Hemisphere ice sheets in good accordance with glacial-geological data (Huybrechts and T'siobbel, 1997).

Runoff (excluding ice calving) from the Laurentide, Cordilleran, Fennoscandian, Kara, Barents and Greenland ice sheets was calculated, but runoff from ice masses in the Southern Hemisphere, such as in Patagonia, is excluded. Runoff from the Antarctic ice sheet is believed to be trivial compared to the fluxes calculated here (Huybrechts and Oerlemans, 1990; Jacobs et al., 1992). Fig. 1 presents the calculated annual runoff from the Northern Hemisphere ice 


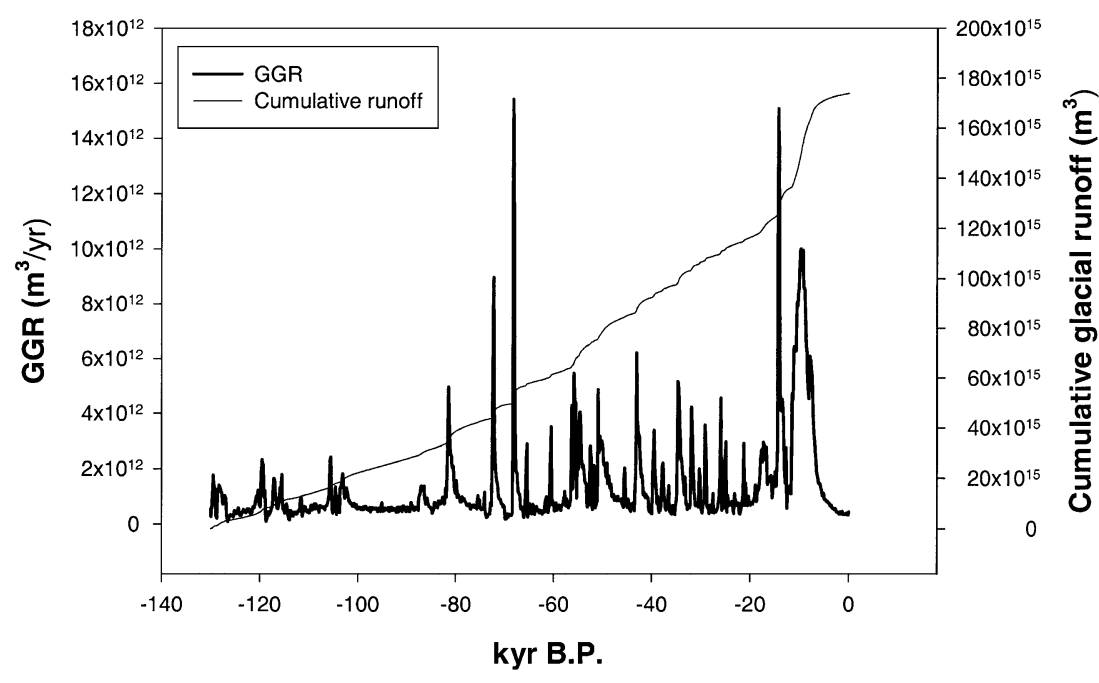

Fig. 1. Modelled global glacial runoff (GGR) and cumulative glacial runoff during the last glacial cycle.

sheets in 100-year intervals from 130 ka B.P. to the present-day.

\subsection{Estimation of glacial ${ }^{*} \mathrm{Ca}^{2+}, \mathrm{HCO}_{3}^{-},{ }^{*} \mathrm{SO}_{4}^{2-}$,} ${ }^{*} \mathrm{Mg}^{2+},{ }^{*} \mathrm{Na}^{+}$, and ${ }^{*} \mathrm{~K}^{+}$fluxes

The fluxes of $* \mathrm{Ca}^{2+}, \mathrm{HCO}_{3}^{-}$and $* \mathrm{SO}_{4}^{2-}$ fluxes are calculated using both field data (Scenario 1) and theoretical considerations (Scenario 2), while the ${ }^{*} \mathrm{Mg}^{2+},{ }^{*} \mathrm{Na}^{+},{ }^{*} \mathrm{~K}^{+}$and $\mathrm{Si}$ fluxes are calculated from field data alone ${ }^{*}$ denotes sea salt corrected values, assuming that all $\mathrm{Cl}^{-}$in the meltwaters is derived from sea salt, using the composition of seawater given by Holland (1978)). Currently, there are only a limited number of high-quality chemical and runoff data sets from glacial catchments (Sharp,
1996), and these catchments contain small valley glaciers rather than ice caps or ice sheets. The problems of "scaling up" from small to large masses are addressed below. The five glaciated catchments shown in Table 1 have a lithology that is predominantly silicate-based, although two of the catchments contain carbonate. Much of the bedrock over which the ice sheets of the Northern Hemisphere grew was continental shield and granite (Gibbs and Kump, 1994), hence the lithology of the glaciated catchments presented in Table 1 is potentially more geochemically reactive. We argue below that it is the trace sulphide and carbonate (and perhaps the organic carbon) content of the bedrock that is important in determining the magnitude of glacial chemical denudation. Thus, provided that the comminuted continen-

Table 1

Catchment area, basal thermal regime and bedrock lithology of the five glaciated catchments

\begin{tabular}{llll}
\hline Glacier & $\begin{array}{l}\text { Catchment } \\
\text { area }\left(\mathrm{km}^{2}\right)\end{array}$ & $\begin{array}{l}\text { Basal thermal } \\
\text { regime }\end{array}$ & Bedrock \\
\hline Haut Glacier d'Arolla, Swiss Alps & 12 & warm-based & gneiss, amphibolite, granite \\
Glacier du Bossons, French Alps $^{2}$ & 16 & warm-based & gneiss, granite \\
Austre Brøggerbreen, Svalbard & 11 & cold-based & sandstone, limestone, shale \\
Finsterwalderbreen, Svalbard & 68 & colythermal-based & sandstone, limestone, shale, dolomitic carbonate \\
Scott Turnerbreen, Svalbard $^{5}$ & 13 & shale \\
\hline
\end{tabular}

Full descriptions of the catchments, sampling, sample treatment and analysis can be found in: (1) Sharp et al. (1995), (2) Tranter (1982), (3) Tranter et al. (1996), (4) Wadham et al. (1999), (5) Hodgkins et al. (1998). 
tal shield contains these minerals, the runoff chemistry is likely to be broadly similar. We have not included data from wholly carbonate catchments, which are potentially more geochemically reactive than silicate catchments. This is because carbonates underlay only small sectors of the Laurentide Ice Sheet and we aim to produce flux estimates that are as conservative as our current data sets allow.

Representative concentrations of each species in runoff from a particular catchment are derived from best fit linear regression of the flux of the species vs. discharge. The flux is a linear function of discharge (see Fig. 2), which is partly a consequence of discharge being a component of the dependant variable as well as the independent variable. We define the representative concentration of each species in the runoff as the slope of the regression equation. This method of estimating the representative concentration is used because it gives weight to the low concentrations at higher discharge that produce the greatest chemical fluxes, and it produces a term that is readily combined with the glacial runoff estimates to give a global glacial chemical flux. Table 2 documents the range of representative concentrations of major ions and $\mathrm{Si}$ for each of the five glacial catchments, and the mean of the representative values.

Glacial solute concentrations calculated in the above manner are conservative, since the linear regression of flux vs. discharge usually produces

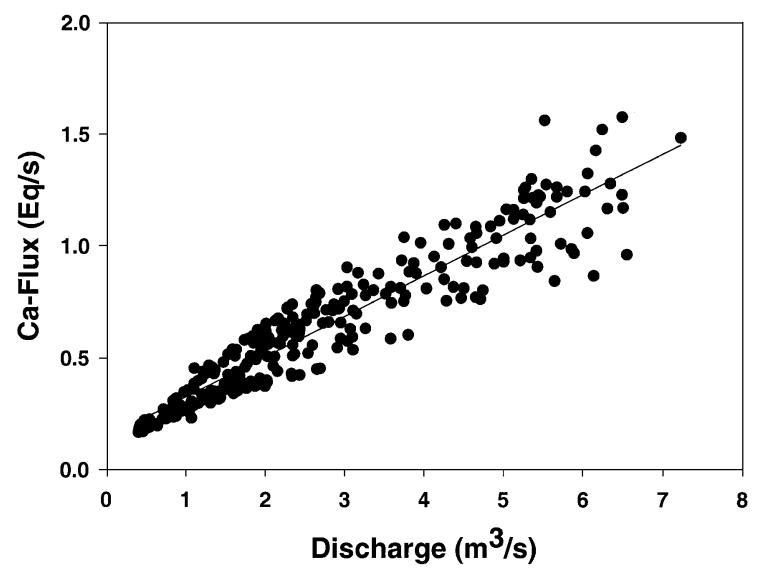

Fig. 2. The association between calcium flux and discharge for the Haut Glacier d'Arolla. Data is from the 1989 and 1990 field seasons. See Sharp et al. (1995) for more details. positive intercepts that are significantly different from zero (see Table 2). Total dissolved inorganic carbon (DIC) is set at $232 \mu \mathrm{eq} / 1\left(230 \mu \mathrm{eq} / 1\right.$ of $\mathrm{HCO}_{3}^{-}$and 2 $\mu$ eq/ 1 of $\mathrm{H}_{2} \mathrm{CO}_{3}$ ) and total alkalinity (TA) is set as 230 $\mu$ eq/l. These representative concentrations are multiplied by the annual glacial runoff, as calculated above, to give annual glacial solute fluxes, which are referred to as Scenario 1.

Theoretical fluxes of $* \mathrm{Ca}^{2+},{ }^{*} \mathrm{SO}_{4}^{2-}$ and $\mathrm{HCO}_{3}^{-}$ are calculated as follows, and are referred to as Scenario 2 in an attempt to quantify the maximum potential glacial stimulation of the oceans to release $\mathrm{CO}_{2}$. We assume that all meltwaters react with carbonates in environments that are closed with respect to the atmosphere and that carbonate hydrolysis (Eq. (4)) proceeds until the solution is saturated with respect to calcite at $0{ }^{\circ} \mathrm{C}$. Based on PHREEQC Version 1.6 (Parkhurst, 1995), we calculate that such a solution contains $208 \mu \mathrm{eq} / 1$ of $\mathrm{Ca}^{2+}, 48.6 \mu \mathrm{eq} / 1$ of $\mathrm{HCO}_{3}^{-}, 111 \mu \mathrm{eq} / 1$ of $\mathrm{CO}_{3}^{2-}$ and has a $\mathrm{pH}$ of 10.61 . We assume that, initially, all surface meltwaters are saturated with respect to atmospheric $\mathrm{O}_{2}$ at sea level and at $0{ }^{\circ} \mathrm{C}$ (i.e., $p \mathrm{O}_{2}=0.209 \mathrm{~atm}$, giving rise to 305 $\mu \mathrm{mol} / 1$ of $\mathrm{O}_{2}$ ), that all $\mathrm{O}_{2}$ oxidises sulphides (Eq. (5)) in subglacial environments that are closed with respect to the atmosphere, and that the acidity generated by the sulphide oxidation is entirely consumed by carbonate dissolution. Eq. (5) suggests that some $650 \mu \mathrm{eq} / 1$ of $\mathrm{Ca}^{2+}$ should be dissolved, but side reactions involving $\mathrm{Fe}(\mathrm{II})$ and $\mathrm{Fe}(\mathrm{III})$ compounds and changes in carbonate speciation result in enhanced dissolution of carbonate. A solution with $\mathrm{pH}$ of $9.29, \mathrm{Ca}^{2+}=700 \mu \mathrm{eq} / 1, \mathrm{SO}_{4}^{2-}=326 \mu \mathrm{eq} / 1$, $\mathrm{HCO}_{3}^{-}=327 \mu \mathrm{eq} / 1$ and $\mathrm{CO}_{3}^{2-}=44.4 \mu \mathrm{eql} / 1$ results. The total dissolved inorganic carbon (DIC) and the total alkalinity (TA) of the solution are $350 \mu \mathrm{mol} / \mathrm{l}$ and $374 \mu \mathrm{eq} / \mathrm{l}$, respectively. This solution is allowed to equilibrate with atmospheric $\mathrm{CO}_{2}$, at a typical glacial-interglacial average $p \mathrm{CO}_{2}$ of $240 \mu \mathrm{atm}$, to simulate $\mathrm{CO}_{2}$ uptake during transit of meltwaters to the coast. The DIC concentration increases to 391 $\mu \mathrm{mol} / 1 \quad\left(\mathrm{CO}_{2}=18.7 \mu \mathrm{mol} / 1, \mathrm{HCO}_{3}^{-}=372 \mu \mathrm{eq} / \mathrm{l}\right.$ and $\mathrm{CO}_{3}^{2-}$ of $1.8 \mu \mathrm{eql} / \mathrm{l}$ ) and the $\mathrm{pH}$ decreases to 7.86 . Some $350 \mu \mathrm{mol} / \mathrm{l}$ of the DIC comes from carbonate minerals, while the remaining $41.6 \mu \mathrm{mol} / 1$ comes from the atmosphere. TA remains unchanged during reequilibration. These concentrations are multiplied by the annual glacial runoff, as calculated above, to 
Table 2

Representative concentrations of ions in five glaciated catchments

\begin{tabular}{|c|c|c|c|c|c|}
\hline \multirow[t]{2}{*}{ Glacier } & \multicolumn{5}{|c|}{ Representative concentration $(\mu \mathrm{eq} / \mathrm{l})$} \\
\hline & $* \mathrm{Ca}^{2+}$ & $* \mathrm{Mg}^{2+}$ & $* \mathrm{Na}^{+}+* \mathrm{~K}^{+}$ & $* \mathrm{SO}_{4}^{2-}$ & $\mathrm{HCO}_{3}^{-}$ \\
\hline Haut Glacier d'Arolla & $183 \pm 4$ & $22 \pm 1$ & $16 \pm 1$ & $21 \pm 1$ & $214 \pm 4$ \\
\hline Glacier du Bossons & $184 \pm 28$ & $4.8 \pm 0.8$ & $60 \pm 8$ & $64 \pm 17$ & $146 \pm 26$ \\
\hline Austre Brøggerbreen & $137 \pm 12$ & $26 \pm 3$ & $3.4 \pm 1.9$ & $4.4 \pm 1.4$ & $241 \pm 13$ \\
\hline Finsterwalderbreen & $380 \pm 7$ & $112 \pm 5$ & $44 \pm 4$ & $101 \pm 5$ & $365 \pm 6$ \\
\hline Scott Turnerbreen & $126 \pm 8$ & $94 \pm 3$ & $65 \pm 11$ & $98 \pm 5$ & $164 \pm 14$ \\
\hline \multirow[t]{2}{*}{ Mean } & 202 & 52 & 38 & 58 & \\
\hline & & & $\mathbf{\Sigma}^{+}=\mathbf{2 9 2}$ & & $\mathbf{\Sigma}^{-}=\mathbf{2 8 8}$ \\
\hline \multirow[t]{2}{*}{ Glacier } & \multicolumn{5}{|c|}{ Regression intercepts, $r^{2}$ values $(n)$} \\
\hline & $* \mathrm{Ca}^{2+}$ & $* \mathrm{Mg}^{2+}$ & $* \mathrm{Na}^{+}+* \mathrm{~K}^{+}$ & $* \mathrm{SO}_{4}^{2-}$ & $\mathrm{HCO}_{3}^{-}$ \\
\hline \multirow[t]{2}{*}{ Haut Glacier d'Arolla } & $142 \pm 12$ & $13 \pm 2$ & $11 \pm 2$ & $109 \pm 5$ & $77 \pm 12$ \\
\hline & $0.89(281)$ & $0.80(282)$ & 0.79 (237) & $0.43(279)$ & $0.91(300)$ \\
\hline \multirow[t]{2}{*}{ Glacier du Bossons } & $13 \pm 6$ & $0.4 \pm 0.2$ & $3.7 \pm 1.7$ & $6 \pm 3$ & $13 \pm 5$ \\
\hline & $0.76(14)$ & $0.72(14)$ & $0.79(14)$ & $0.52(14)$ & $0.72(14)$ \\
\hline \multirow[t]{2}{*}{ Austre Brøggerbreen } & $86 \pm 26$ & $32 \pm 6$ & $0.2 \pm 4$ & $17 \pm 3$ & $5 \pm 26$ \\
\hline & $0.69(57)$ & $0.62(60)$ & $0.06(54)$ & $0.13(61)$ & $0.86(61)$ \\
\hline \multirow[t]{2}{*}{ Finsterwalderbreen } & $396 \pm 56$ & $251 \pm 35$ & $52 \pm 27$ & $463 \pm 39$ & $227 \pm 43$ \\
\hline & $0.96(101)$ & $0.85(101)$ & $0.62(96)$ & $0.79(103)$ & $0.98(102)$ \\
\hline \multirow[t]{2}{*}{ Scott Turnerbreen } & $14 \pm 10$ & $5 \pm 3$ & $-6 \pm 12$ & $11 \pm 5$ & $44 \pm 16$ \\
\hline & $0.89(29)$ & $0.97(29)$ & $0.54(29)$ & $0.94(29)$ & $0.83(28)$ \\
\hline
\end{tabular}

The representative concentrations are derived from the linear regression of ion flux vs. discharge, and are equal to the regression slopes. Regression intercepts and $r^{2}$ values for the regression equations are found in the lower half of the table. Standard errors of the regression slopes and intercepts are given, and $n$ denotes the number of observations. Samples were collected throughout the ablation season at all glaciers, apart from Glacier du Bossons, where data is available for only 2 days in the summer.

produce a theoretical annual glacial flux of $* \mathrm{Ca}^{2+}$, * $\mathrm{SO}_{4}^{2-}$ and $\mathrm{HCO}_{3}^{-}$.

\subsection{Estimation of $\mathrm{CO}_{2}$ perturbation by glacial solutes via a carbon cycling model}

The potential of glacial chemical weathering to perturb atmospheric $\mathrm{CO}_{2}$ concentrations is quantified by using the glacial solute fluxes (Scenarios 1 and 2) as inputs to an ocean carbon cycle model, which is a recent version of the model described in Munhoven and François $(1994,1996)$. The model represents the ocean-atmosphere subsystem of the global carbon cycle as a set of 11 homogeneous reservoirs (1 atmospheric and 10 oceanic). The geometry of the oceanic reservoirs is not static, but changes as a function of the prescribed sea level evolution, based upon five realistic profiles of sea floor depth distribution. Water fluxes between the oceanic reservoirs remain constant at their present-day values. The model includes mass balance equations for dissolved inorganic carbon (DIC), total alkalinity (TA), phosphate (chosen as the limiting nutrient) and oxygen in the oceanic reservoirs, $p \mathrm{CO}_{2}$ in the atmospheric reservoir, and for the $\delta^{13} \mathrm{C}$ and $\Delta^{14} \mathrm{C}$ isotopic characteristics of them all. The mass balance equations include terms to represent the air-sea exchange of $\mathrm{CO}_{2}$, the transport of dissolved species by the water

Table 3

Values for the various percentiles of global glacial runoff (GGR) over the last $130 \mathrm{ka}$, and a comparison of these values with current global riverine discharge (GRD, $4.6 \times 10^{13} \mathrm{~m}^{3} /$ year; Holland, 1978)

\begin{tabular}{lll}
\hline Percentile & $\begin{array}{l}\text { Global glacial } \\
\text { runoff } \\
\left(\times 10^{12} \mathrm{~m}^{3} / \text { year }\right)\end{array}$ & $\begin{array}{l}\text { Percentage } \\
\text { of current global } \\
\text { riverine runoff }\end{array}$ \\
\hline 25 & 0.55 & 1.2 \\
50 & 0.74 & 1.6 \\
75 & 1.4 & 3 \\
90 & 2.7 & 5.9 \\
95 & 4.5 & 9.8 \\
99 & 8.9 & 19 \\
\hline
\end{tabular}


circulation. Further taken into account is the production of organic and of inorganic (carbonate) particles by biological activity in the surface reservoirs. Organic particles rain down to the intermediate and deep reservoirs, where they are completely remineralised and their constituents released back to solution. Inorganic particles fall down to the sea floor where they collect in the sedimentary mixed layer. A fully coupled model of the upper sediment column at 80 sea floor depth levels for each of the five bathymetric profiles is then used to determine the ocean-sediment exchange of carbonate particles. Depending on the degree of supersaturation with respect to calcite and aragonite at each depth level, carbonate particles may either dissolve, and their dissolution products diffuse back to the ocean, or accumulate and become buried in deeper sediment. The required saturation depths are calculated from the concentrations of $\mathrm{CO}_{3}^{2-}$ in the deep reservoirs and the thermodynamic solubility products of calcite and aragonite. The sediment model generates vertical sediment profiles and can therefore take into account chemical erosion of deep-sea sediments.

A separate scheme is used to represent the carbonate accumulation rate in coral reefs and on banks and shelves in the continental shelf zone. Both fluxes vary as a function of sea level and of sea level variation rate. Finally, the mass balance equations also include terms to take into account the consumption of atmospheric $\mathrm{CO}_{2}$ and the transfer of bicarbonate to the ocean due to continental weathering processes, as well as the (related) supply of $\mathrm{CO}_{2}$ to the ocean-atmosphere system by volcanic and hydrothermal activity. Scenarios for these different terms need to be prescribed. We then use the model to calculate the impact of various weathering scenarios on the evolution of the global distributions of dissolved inorganic carbon and of total alkalinity, and thus of $\mathrm{CO}_{2}$ in the atmosphere and, equally interesting, the concentration of $\mathrm{CO}_{3}^{2-}$ in the deep sea. This latter dynamically adjusts in such a way that the overall losses of dissolved inorganic carbon and of total alkalinity through carbonate burial in the sea floor sediments matches the transfer of carbon from the crust to the ocean-atmosphere, and the supply of alkalinity by weathering processes as closely as possible.

The model version used here is only slightly different from the one described in Munhoven and François (1996). The number of adjustable parameters (phosphate utilisation ratios, rain ratios, carbonate dissolution rate etc.) was reduced from 16 to 12 . The

Table 4

Percentiles of global glacial fluxes (GGF) of major base cations and anions $\left(\times 10^{9}\right.$ eq/year) over the last 130 ka and a comparison with current global riverine fluxes (GRF) as determined by Holland (1978)

\begin{tabular}{|c|c|c|c|c|c|c|c|c|c|c|}
\hline \multicolumn{11}{|l|}{ Scenario 1} \\
\hline Percentile & $\begin{array}{l}\mathrm{GGF}- \\
* \mathrm{Ca} \\
\end{array}$ & $\begin{array}{l}\% * \mathrm{Ca}- \\
\mathrm{GRF}\end{array}$ & $\begin{array}{l}\mathrm{GGF}- \\
* \mathrm{Mg}\end{array}$ & $\begin{array}{l}\% * \mathrm{Mg}- \\
\mathrm{GRF}\end{array}$ & $\begin{array}{l}\mathrm{GGF}- \\
* \mathrm{Na}+* \mathrm{~K}\end{array}$ & $\begin{array}{l}\%(* \mathrm{Na}+* \mathrm{~K}) \\
\mathrm{GRF}\end{array}$ & $\begin{array}{l}\mathrm{GGF}- \\
\mathrm{HCO}_{3}\end{array}$ & $\begin{array}{l}\% \mathrm{HCO}_{3} \\
\text { GRF }\end{array}$ & $\begin{array}{l}\mathrm{GGF}- \\
* \mathrm{SO}_{4}\end{array}$ & $\begin{array}{l}\% * \mathrm{SO}_{4} \\
\mathrm{GRF}\end{array}$ \\
\hline 25 & 110 & 0.3 & 29 & 0.2 & 21 & 0.3 & 130 & 0.3 & 32 & 0.4 \\
\hline 50 & 150 & 0.4 & 39 & 0.3 & 28 & 0.4 & 170 & 0.4 & 43 & 0.5 \\
\hline 75 & 280 & 0.8 & 73 & 0.6 & 53 & 0.7 & 320 & 0.8 & 81 & 0.9 \\
\hline 90 & 550 & 1.6 & 140 & 1.1 & 100 & 1.4 & 620 & 1.5 & 160 & 1.7 \\
\hline 95 & 910 & 2.7 & 230 & 1.8 & 170 & 2.4 & 1000 & 2.5 & 260 & 2.9 \\
\hline 99 & 1800 & 5.2 & 460 & 3.5 & 340 & 4.7 & 2000 & 4.8 & 520 & 5.6 \\
\hline
\end{tabular}

Scenario 2

\begin{tabular}{|c|c|c|c|c|c|c|}
\hline Percentile & $\begin{array}{l}\mathrm{GGF}- \\
* \mathrm{Ca}\end{array}$ & $\begin{array}{l}\% * \mathrm{Ca}- \\
\mathrm{GRF}\end{array}$ & $\begin{array}{l}\mathrm{GGF}- \\
\mathrm{HCO}_{3}\end{array}$ & $\begin{array}{l}\% \mathrm{HCO}_{3}- \\
\mathrm{GRF}\end{array}$ & $\begin{array}{l}\text { GGF- } \\
* \mathrm{SO}_{4}\end{array}$ & $\begin{array}{l}\% \mathrm{SO}_{4}- \\
\mathrm{RF}\end{array}$ \\
\hline 25 & 390 & 1.1 & 210 & 0.5 & 180 & 2.0 \\
\hline 50 & 520 & 1.5 & 280 & 0.7 & 240 & 2.6 \\
\hline 75 & 980 & 2.8 & 520 & 1.2 & 460 & 5.0 \\
\hline 90 & 1900 & 5.6 & 1000 & 2.4 & 880 & 9.8 \\
\hline 95 & 3200 & 9.3 & 1700 & 4.0 & 1500 & 16 \\
\hline 99 & 6200 & 18 & 2300 & 7.8 & 2900 & 31 \\
\hline
\end{tabular}



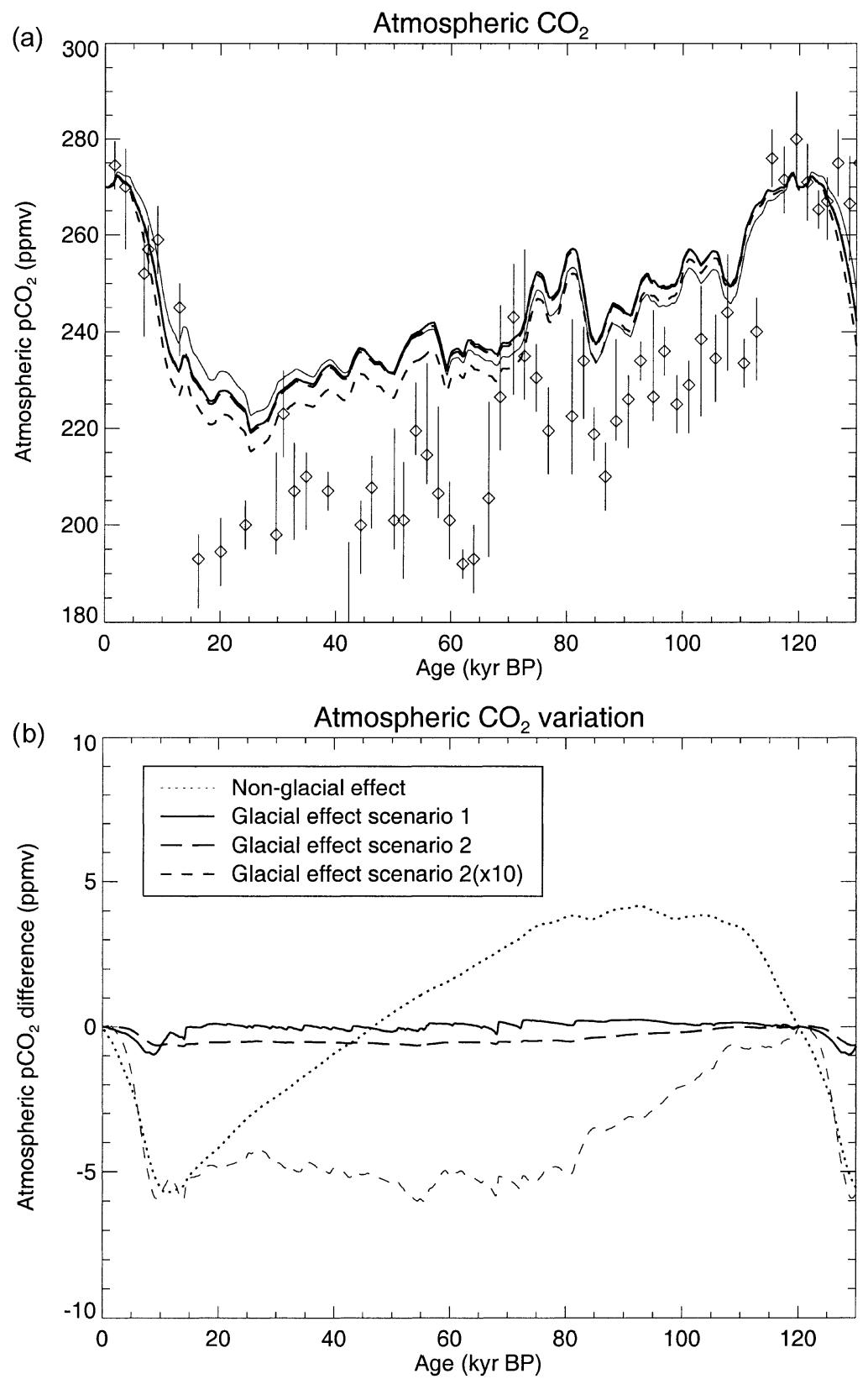

Fig. 3. The potential impact of glacial solute fluxes on atmospheric $\mathrm{CO}_{2}$ concentrations. (a) Variations in atmospheric $\mathrm{CO}_{2}$ concentrations given a number of different scenarios. The thin full line is the baseline, with all terrestrial chemical erosion fluxes held constant. A thin dotted line is masked by the full thick line, and would show the effect of glacial fluxes being held constant, with non-glacial fluxes variable. The thick full line shows the effect of non-glacial and glacial fluxes being variable, as described by Scenario 1 . The thick dashed line is similar, but glacial fluxes are as described by Scenario 2. Finally, the thick short dashed line is similar, but glacial fluxes are for $10 \times$ Scenario 2 . The open diamonds are $\mathrm{CO}_{2}$ concentrations derived from the Vostok ice core (Barnola et al., 1987). (b) Perturbation of atmospheric $\mathrm{CO}_{2}$ by variations in non-glacial and glacial solute fluxes. The thin dotted line shows the effect of variable non-glacial fluxes with glacial fluxes held constant (for more details, see Jones et al., in press). The thick full line shows the effect of solute fluxes described by Scenario 1. The thick dashed line shows the effect of glacial solute fluxes described by Scenario 2, while the thick, short-dashed line shows the effect of glacial solute fluxes as described by $10 \times$ Scenario 2 . 
speciation of the carbonate system is now largely based on the set of parameterisations for the thermodynamical constants presented by Millero (1995). The model has undergone a systematic recalibration (described in Munhoven, 1997) and the values for the model parameters have been adjusted to reproduce a number of oceanographic constraints from the literature.

Jones et al. (2002) have modelled the flux of TA and DIC from non-glaciated terrain to the ocean for the last glacial maximum ( 21 ka B.P.), through four time steps $(16,14,11$ and 6 ka B.P.) during deglaciation, to the present-day. Variations in these parameters are a consequence of changes in the amount and distribution of non-glaciated runoff. We assume that the flux of solute from non-glaciated terrain to the oceans at 120 $\mathrm{ka}$, the onset of the last glaciation, was the same as the present-day, and we apply a linear ramp from 120 to 21 ka to calculate the flux at intervening times. We also apply a linear ramp between the fluxes during deglaciation to calculate non-glacial solute fluxes at time steps of 100 years. These are added to the glaciated fluxes of TA and DIC calculated at similar time steps for Scenarios 1 and 2 to provide the TA and DIC inputs to the carbon cycling model.

\section{Results and discussion}

Our estimate of annual global glacial runoff (hereafter, GGR) is $4.4 \times 10^{11} \mathrm{~m}^{3} /$ year (see Fig. 1). This is of similar magnitude to the current GGR of $\sim 1 \times 10^{12}$ $\mathrm{m}^{3} /$ year) calculated by Gibbs and Kump (1994), inferred from their Table 5. Our estimate is in reasonable agreement with that which can be derived from the literature, namely $2.8-3.3 \times 10^{11} \mathrm{~m}^{3} /$ year $\left(2.8 \times 10^{11} \mathrm{~m}^{3} /\right.$ year from Greenland (Oerlemans, 1993 ) and $0.04-5.3 \times 10^{10} \mathrm{~m}^{3} /$ year from Antarctica (Jacobs et al., 1992)). Current annual global riverine discharge (hereafter, GRD) is $\sim 4.6 \times 10^{13} \mathrm{~m}^{3} /$ year (Holland, 1978). Hence, we estimate current GGR to be $\sim 0.6-1.0 \%$ of GRD.

The average modelled GGR for the last $130 \mathrm{ka}$ is $1.3 \times 10^{12} \mathrm{~m}^{3} /$ year, $\sim 3$ times that calculated for the present-day and $\sim 2.8 \%$ that of GRD. Fig. 1 shows that there are several short periods of elevated GGR during the period from 130 to $15 \mathrm{ka}$ B.P., most notably at 72 and $68 \mathrm{ka}$ B.P., when values approached $\sim 20 \%$ and $\sim 30 \%$ of GRD. Periods of elevated glacial runoff seldom lasted for more than a few hundred years until the main period of ice sheet decay from $\sim 15$ to $5 \mathrm{ka}$ B.P., when maximum runoff reached $\sim 30 \%$ of GRD at $14.3 \mathrm{ka}$ B.P. Table 3 describes the frequency distribution of GGR, and compares these values to current GRD. It can be seen that GGR is only $>3 \%$ of current GRD on $25 \%$ of occasions, and is only $\geq 19 \%$ of GRD on $1 \%$ of occasions.

Table 2 shows the mean representative concentrations of $* \mathrm{Ca}^{2+}, * \mathrm{Mg}^{2+}, * \mathrm{Na}^{+}+* \mathrm{~K}^{+}, \mathrm{HCO}_{3}^{-}$, $* \mathrm{SO}_{4}^{2-}$ and $\mathrm{Si}$. The positive and negative charges balance almost exactly. This may be fortuitous, since it appears that taking the mean of the five representative values averages out some of the errors in the individual data sets for each catchment. For example, there is an apparent excess of negative charge at Austre Brøggerbreen, and an excess of positive charge at Glacier des Bossons, Scott Turnerbreen and Finsterwalderbreen. The major ions are ${ }^{*} \mathrm{Ca}^{2+}$ and $\mathrm{HCO}_{3}^{-}$, while $* \mathrm{Mg}^{2+}$ and $* \mathrm{SO}_{4}^{2-}$ are secondary ions. The representative glacial concentrations are $\sim 25 \%$ those of global mean river water (Holland, 1978).

Table 4 shows the distribution of the glacial fluxes of major ions associated with Scenarios 1 and 2 over the last $130 \mathrm{ka}$, obtained from the product of either GGR and the representative glacial concentrations (Scenario 1) or GGR and the theoretical $* \mathrm{Ca}^{2+}$, $\mathrm{HCO}_{3}^{-}$and $* \mathrm{SO}_{4}^{2-}$ concentrations (Scenario 2), using current global riverine fluxes as a reference. The latter are obtained from the product of current GRD and the composition of global mean river water (Holland, 1978). Scenario 1 produces major ion fluxes that are $>2 \%$ of current global riverine fluxes at the 95th percentile (or the 99th percentile for $* \mathrm{Mg}$ ). By contrast, the 95 th percentiles for fluxes of $* \mathrm{Ca}^{2+}$, $\mathrm{HCO}_{3}^{-}$and $* \mathrm{SO}_{4}^{2-}$ given in Scenario 2 are $9.3 \%$, $4.0 \%$ and $16 \%$ of current global riverine fluxes, respectively. This suggests that small changes in the flux of non-glacial solutes have a comparable or greater effect on total terrestrial chemical erosion rates than the variations we calculate for glacial solute fluxes.

The potential impact of the glacial solutes on ${ }^{\text {atms }} \mathrm{CO}_{2}$ was examined in three different simulations:

a) The glacial and non-glacial chemical erosion fluxes were held constant at their average glacialinterglacial values. This provides a base level for the two following simulations; 
b) Glacial chemical erosion was held constant at the average glacial-interglacial value and non-glacial chemical erosion was allowed to vary;

c) Both glacial and non-glacial chemical erosion were allowed to vary.

The results from the three simulations are shown in Fig. 3a. The first simulation shows the effect of oceanic processes alone (mainly temperature and salinity variation, and basin-to-shelf transfer of carbonate deposition; see Munhoven and François, 1996 for details). Simulation 2 adds the impact of variable non-glacial chemical erosion fluxes alone, the impact of which accounts for the difference between Simulations 2 and 1 (Fig. 3b). Simulation 3 further includes the effect of variable glacial chemical erosion, the impact of which accounts for the difference between Simulations 3 and 2 (Fig. 3b). Fig. 3 also shows the potential impact of glacial fluxes on atmospheric $\mathrm{CO}_{2}$ concentrations given $10 \times$ Scenario 2 as a check on the sensitivity of our flux estimate.

Fig. 3 shows that the first order features of build up and decline in atmospheric $\mathrm{CO}_{2}$ concentrations, as recorded within the Vostok ice core (Barnola et al., 1987), are reproduced by the model, although exact concentrations are not achieved. Agreement is best during interglacials, and concentrations are over estimated during glacials. It is clear that the oceanic processes have the main impact on the change in atmospheric $\mathrm{CO}_{2}$, since perturbation of glacial and non-glacial fluxes produce little effect on modelled atmospheric $\mathrm{CO}_{2}$ concentrations (Fig. 3a). Varying the riverine flux of solutes (Jones et al., 2002) helps to decrease atmospheric $\mathrm{CO}_{2}$ by $\sim 5.5 \mathrm{ppm}$ during the last two glacial maxima, and to increase atmospheric $\mathrm{CO}_{2}$ by $\sim 4 \mathrm{ppm}$ during the last interglacial (see Fig. $3 b)$. By contrast, glacial perturbations have negligible effect, and even $10 \times$ the flux calculated under Scenario 2 only produces at best a perturbation of $\pm 1 \mathrm{ppm}$ in atmospheric $\mathrm{CO}_{2}$ concentrations during the last glacial cycle. This conclusion is consistent with that reached by Ludwig et al. (1999).

\section{Conclusions}

The first modelled runoff record from the great ice sheets in the Northern Hemisphere during the last glacial cycle (130 ka B.P. to the present) is the basis for estimating glacial solute fluxes using field data and theoretical means. Representative glacial solute concentrations of major ions are $\sim 25 \%$ those of current global river water concentrations. The glacial solute fluxes derived from the field data are usually $<2 \%$ of current riverine fluxes of major cations and anions for $95 \%$ of occasions, and are only $\sim>5 \%$ for $1 \%$ of the last glacial cycle. The likely perturbation of atmospheric $\mathrm{CO}_{2}$ concentrations as a consequence of glacial solute fluxes is $<1 \mathrm{ppm}$ during the last glacial cycle.

\section{Acknowledgements}

This work was Funded by NERC grant nos. GR3/ 11080 \& GR3/11689. GM is a Research Associate with the Belgium Fund for Scientific Research.

\section{References}

Alley, R.B., 1996. Towards a hydrologic model for computerized ice sheet simulations. Hydrol. Process. 10, 649-660.

Anderson, S.A., Drever, J.I., Humphrey, N.F., 1997. Chemical weathering in glacial environments. Geology 25, 399-402.

Arnold, N., Sharp, M., 1992. Influence of glacier hydrology on the dynamics of a large Quaternary ice sheet. J. Quat. Sci. 7, 109-124.

Barnola, J.M., Raynaud, D., Korotkevich, Y.S., Lorius, C., 1987. Vostok ice core provides 160,000 year record of atmospheric $\mathrm{CO}_{2}$. Nature 329, 408-414.

Bentley, C.R., 1987. Antarctic ice streams: a review. J. Geophys. Res. 92 (B9), 8843-8858.

Berner, R.A., Lasaga, A.C., Garrels, R.M., 1983. The carbonatesilicate geochemical cycle and its effect on atmospheric carbon dioxide over the past 100 million years. Am. J. Sci. 283, 641-683.

Brown, G.H., Tranter, M., Sharp, M.J., Gurnell, A.M., 1994. The impact of post mixing chemical reactions on the major ion chemistry of bulk meltwaters draining the Haut Glacier d'Arolla, Valais, Switzerland. Hydrol. Process. 8, 465-480.

Clark, P.U., Licciardi, J.M., MacAyeal, D.R., Jenson, J.W., 1996. Numerical reconstruction of a soft-bedded Laurentide Ice Sheet during the last glacial maximum. Geology 24 (8), 679-682.

Dansgaard, W., Johnson, S.J., Clausen, H.B., Dahl-Jensen, D., Gundestrup, N.S., Hammer, C.U., Hvidberg, C.S., Steffensen, J.P., Sveinbjornsdottir, A.E., Jouzel, J., Bond, G., 1993. Evidence for general instability of past climate from a $250-\mathrm{kyr}$ ice-core record. Nature 364, 218-220.

Gibbs, M.T., Kump, L.R., 1994. Global chemical erosion during the last glacial maximum and the present: sensitivity to changes in lithology and hydrology. Paleoceanography 9, 529-543.

Hallet, B., Hunter, L., Bogen, J., 1996. Rates of erosion and sedi- 
ment evacuation by glaciers: a review of field data and their implications. Glob. Planet. Change 12, 213-235.

Hodgkins, R., Tranter, M., Dowdeswell, J.A., 1998. The hydrochemistry of runoff from a 'cold-based' glacier in the High Arctic (Scott Turnerbreen, Svalbard). Hydrol. Process. 12, 87-104.

Hodson, A.J., Tranter, M., Dowdeswell, J.A., Gurnell, A.M., Hagen, J.O., 1997. Glacier thermal regime and suspended sediment yield: a comparison of two high Arctic glaciers. Ann. Glaciol. $24,32-37$.

Holland, H.D., 1978. The Chemistry of Atmospheres and Oceans Wiley Interscience, $351 \mathrm{pp}$.

Huybrechts, P., 1990. A 3D model for the Antarctic ice sheet: a sensitivity study on the glacial-interglacial contrast. Clim. Dyn. 5, 79-92.

Huybrechts, P., Oerlemans, J., 1990. Response of the Antarctic ice sheet to future greenhouse warming. Clim. Dyn. 5, 93-102.

Huybrechts, P., T'siobbel, S., 1995. Thermomechanical modelling of Northern Hemisphere ice sheets with a two level mass balance parameterization. Ann. Glaciol. 21, 111-116.

Huybrechts, P., T'siobbel, S., 1997. A three-dimensional climate/ice sheet model applied to the Last Glacial Maximum. Ann. Glaciol. 24.

Huybrechts, P., Letreguilly, A., Reeh, N., 1991. The Greenland ice sheet and greenhouse warming. Palaeogeogr. Palaeoclimatol. Palaeoecol. (Global and Planetary Change Section) 89, 399-412.

Jacobs, S.S., Helmer, H.H., Doake, C.S.M., Jenkins, A., Frolich, R.M., 1992. Melting of ice shelves and the mass balance of Antarctica. J. Glaciol. 38, 375-387.

Jones, I.W., Munhoven, G., Tranter, M., Huybrechts, P., Sharp, M.J., 2002. Modelled glacial and non-glacial $\mathrm{HCO}_{3}^{-}, \mathrm{Si}$ and Ge fluxes since the LGM: little potential for impact on atmospheric $\mathrm{CO}_{2}$ concentrations and the marine Ge:Si ratio. Glob. Planet. Change 33, 139-153.

Kump, L.R., Alley, R.B., 1994. Global chemical weathering on glacial time scales. In: Usselman, T.M., Hay, W.W. (Eds.), Material Fluxes on the Surface of the Earth. National Academy Press, Washington, DC. Geophysics Study Committee, National Research Council, pp. 46-60.

Ludwig, W., Ammiotte-Suchet, P., Probst, J.-L., 1999. Enhanced chemical weathering of rocks during the last glacial maximum: a sink for atmospheric $\mathrm{CO}_{2}$ ? Chem. Geol. 159, 147-161.

MacAyeal, D.R., 1993. Binge/purge oscillations of the Laurentide ice sheet as a cause of the North Atlantic's Heinrich events. Palaeoceanography $8,775-784$.

Millero, F.J., 1995. Thermodynamics of the carbon dioxide system in the oceans. Geochim. Cosmochim. Acta 59 (4), 661-677.

Munhoven, G., 1997. Modelling Glacial-Interglacial Atmospheric $\mathrm{CO}_{2}$ Variations: The Role of Continental Weathering. PhD thesis, Université de Liège, Belgium.

Munhoven, G., François, L.M., 1994. Glacial-interglacial changes in continental weathering: possible implications for atmospheric $\mathrm{CO}_{2}$. In: Zahn, R., Pedersen, T.F., Kaminski, M.A., Labeyrie, L. (Eds.), Carbon Cycling in the Glacial Ocean: Constraints on the Ocean's Role in Global Change. Springer-Verlag, Berlin, pp. 39-58, NATO ASI I17.
Munhoven, G., François, L.M., 1996. Glacial-interglacial variability of atmospheric $\mathrm{CO}_{2}$ due to changing continental silicate rock weathering: a model study. J. Geophys. Res. 101 (D16), $21423-21437$.

Oerlemans, J., 1993. Evaluating the role of climate cooling in iceberg production and the Heinrich events. Nature 364, 783-786.

Parkhurst, D.L., 1995. User's guide to PHREEQC - a computer program for speciation, reaction path, advective-transport, and inverse geochemical calculations. USGS Water-resources Investigations Report 95-4227.

Reeh, N., 1989. Parameterization of melt rate and surface temperature on the Greenland ice sheet. Polarforschung 59, 113-128.

Sharp, M., 1996. Weathering pathways in glacial environmentshydrological and lithological controls. In: Bottrell, S.H. (Ed.), Proceedings of the Fourth International Symposium on the Geochemistry of the Earth's Surface, Ilkley, pp. 652-655.

Sharp, M.J., Tranter, M., Brown, G.H., Skidmore, M., 1995. Rates of chemical denudation and $\mathrm{CO}_{2}$ drawdown in a glacier-covered Alpine catchment. Geology 23, 61-64.

Sharp, M., Parkes, J., Cragg, B., Fairchild, I.J., Lamb, H., Tranter, M., 1999. Bacterial populations at glacier beds and their relationship to rock weathering and carbon cycling. Geology 27, $107-110$.

Tranter, M., 1982. Controls on the chemical composition of Alpine glacial meltwater. Unpublished PhD thesis, University of East Anglia.

Tranter, M., 1996. Glacial runoff as a sink for atmospheric $\mathrm{CO}_{2}$ during the last glacial-interglacial transition. In: Bottrell, S.H. (Ed.), Proceedings of the Fourth International Symposium on the Geochemistry of the Earth's Surface, Ilkley, pp. 709-713.

Tranter, M., Brown, G.H., Raiswell, R., Sharp, M.J., Gurnell, A.M., 1993. A conceptual model of solute acquisition by Alpine glacial meltwaters. J. Glaciol. 39, 573-581.

Tranter, M., Brown, G.H., Hodson, A., Gurnell, A.M., 1996. Hydrochemistry as an indicator of the nature of subglacial drainage system structure: a comparison of Arctic and Alpine environments. Hydrol. Process. 10, 541-556.

Tranter, M., Sharp, M.J., Lamb, H.R., Brown, G.H., Hubbard, B.P., Willis, I.C., in press. Geochemical weathering at the bed of Haut Glacier d'Arolla, Switzerland-a new model. Hydrol. Process. 16, 959-993.

Wadham, J.L., Hodson, A.J., Tranter, M., Dowdeswell, J.A., 1999. The hydrochemistry of meltwaters draining a polythermalbased, high Arctic glacier, Svalbard: I. The ablation season. Hydrol. Process.

Wadham, J.L., Tranter, M., Dowdeswell, J.A., 2000. The hydrochemistry of meltwaters draining a polythermal-based, high Arctic glacier, Svalbard: II. Winter and early Spring. Hydrol. Process. 14, 1767-1786.

Walker, J.C.G., Hays, P.B., Kasting, J.F., 1981. A negative feedback mechanism for the long-term stabilisation of Earth's surface temperature. J. Geophys. Res. 86, 9776-9782. 